\title{
The Calculation of China's Financial Stability Index--Based on Improved Analytic Hierarchy Process and Entropy
}

\author{
Xuyan $\mathrm{Du}^{1}$, a , Shuai $\mathrm{Li}^{2, \mathrm{~b}}$ \\ ${ }^{1}$ School of Mathematics, Tongji University, Shanghai 201800, China; \\ 2Department of Computer Science, Tongji University, Shanghai 201800, China. \\ a1328474965@qq.com, btongjicslishuai@gmail.com
}

\begin{abstract}
This article selects the seven first-class indexes of international financial stability index, macroeconomic stability index and so on. And according to the situation of China, multiple secondary indexes are selected under the first-class indexes. We adopt the improved AHP and entropy to calculate the weight of each second-grade index respectively, which lead to a conclusion that the gap between the results is not big and the agreement is very high. Therefore, the average value of the two methods is chosen as the final weight for the calculation. And the fuzzy evaluation method is used to calculate the financial stability index-take inflation index as an example to construct the relative membership vector and explain its calculation process. This method provides a way for regulators to measure regulation.
\end{abstract}

Keywords: China's financial stability index, improved AHP, entropy.

\section{Literature Review}

There are different definitions of financial stability in terms of institutions and scholars. Among them, two types of perspectives are most widely recognized. Among many definitions of financial stability, the financial system has always been based on two elements, although the contents are different. One is that the financial system performs its economic function, and the other is that the financial system can withstand certain external shocks (Xu Guoxiang, Guo Jianna and Chen Fuping, 2017).

The former definition refers to Padoa-Schioppa (2003), which considers financial stability to mean that the financial system is capable of withstanding shocks, the allocation of deposits to investment opportunities and payments in economic activities addresses the disruptive effects of the process of accumulation without shocks. The Federal Reserve Board understands financial instability from the perspective of Finance Instability, the definition of financial stability as non-existence of financial instability suggests that financial instability refers to a situation in which the price of certain important financial assets deviates significantly from the base value and where there are serious distortions in the functioning of financial markets and in the issuance of credit, which hampers economic growth. The latter definition is represented by Houbcn and Kakes(2004). They believe that financial stability is a state in which the financial system can effectively allocate resources across industries and time, evaluate and manage financial risks and absorb risks. The European Central Bank considers financial stability to mean that financial institutions, financial markets and financial infrastructure are functioning well and can maintain an effective transformation of savings into investment in the face of various shocks. The Peoples Bank of China has also defined financial stability in its 2005 Financial Stability Report, which considers that financial stability means that the financial system is in a stable state capable of effectively carrying out its key functions.

\section{Index System Construction}

Starting from the connotation of financial stability, this article selects international financial stability, macroeconomic stability index, the index of financial market stability, the banking stability index and stability index for the securities industry, insurance industry stability index and nonfinancial sector stability index seven first-level indicators, according to China's national conditions under the primary index selecting multiple secondary indexes. As the following table: 
Table 1. Indexes table

\begin{tabular}{|c|c|c|}
\hline First level indicators & The secondary indicators & note \\
\hline \multirow{2}{*}{$\begin{array}{l}\text { International financial } \\
\text { stability index }\end{array}$} & Ted spread & $\begin{array}{l}\text { Liquidity pressures in banking } \\
\text { markets }\end{array}$ \\
\hline & VIX & $\begin{array}{l}\text { The stock market as a whole } \\
\text { fluctuates in price }\end{array}$ \\
\hline \multirow{5}{*}{$\begin{array}{l}\text { Macroeconomic } \\
\text { stability index }\end{array}$} & The GDP growth rate & Economic growth \\
\hline & Inflation rate & Price stability \\
\hline & Fiscal deficit /GDP & The fiscal situation \\
\hline & Current account balance /GDP & The balance of payments \\
\hline & $\begin{array}{l}\text { Foreign exchange reserves/short- } \\
\text { term foreign debt }\end{array}$ & solvency \\
\hline \multirow{4}{*}{$\begin{array}{l}\text { Financial market } \\
\text { stability index }\end{array}$} & Shanghai stock price/earnings ratio & The securities market \\
\hline & $\begin{array}{l}\text { The rate at which Banks lend to } \\
\text { each other for seven days }\end{array}$ & The money market \\
\hline & $\begin{array}{l}\text { The real effective exchange rate of } \\
\text { RMB }\end{array}$ & The foreign exchange market \\
\hline & The real estate price index & Real estate market \\
\hline \multirow{5}{*}{ Banking stability index } & Bank broad credit growth & $\begin{array}{l}\text { Assets and liabilities (including off- } \\
\text { balance sheet financing) }\end{array}$ \\
\hline & Inter-bank debt ratio & Assets and liabilities \\
\hline & $\begin{array}{l}\text { The bank's non-performing loan } \\
\text { ratio }\end{array}$ & Asset quality \\
\hline & Bank capital adequacy ratio & Capital and leverage \\
\hline & Liquidity coverage & Liquidity \\
\hline \multirow{3}{*}{$\begin{array}{l}\text { Securities industry } \\
\text { stability index }\end{array}$} & Risk coverage & Risk coverage \\
\hline & Capital leverage ratio & Capital and leverage \\
\hline & Liquidity coverage & Liquidity \\
\hline \multirow{2}{*}{$\begin{array}{l}\text { Insurance stability } \\
\text { index }\end{array}$} & Solvency adequacy ratio & solvency \\
\hline & Integrated flow rate & Liquidity \\
\hline \multirow{3}{*}{$\begin{array}{l}\text { Non-financial sector } \\
\text { stability indicators }\end{array}$} & Local government debt /GDP & Local government debt risk \\
\hline & $\begin{array}{l}\text { The asset-liability ratio of } \\
\text { industrial enterprises }\end{array}$ & Non-financial corporate debt \\
\hline & Household debt /GDP & Household leverage ratio \\
\hline
\end{tabular}

\section{Financial Stability Index Weight Calculation}

Through the understanding of literature reading and methods, this paper finally chooses to use objective methods and subjective methods to calculate weights separately. The objective method is the entropy method, which is based on historical data that affect financial stability variables, the weight of each index is calculated, and then the weight of each index to the total index is calculated. Then a comprehensive index to evaluate the financial stability of China is obtained. The subjective method is the improved analytic hierarchy process, the two methods use the expert scoring method, through the matrix transformation, finally get the weight of each index.

Based on the objective data, the quarterly data between 2010 and 2017 are selected. See the appendix for detailed data. Through the above calculation process, the weight of secondary indicators on corresponding primary indicators is obtained as follows: 
Table 2 quarterly data between 2010 and 2017

\begin{tabular}{|c|c|c|c|c|}
\hline First level indicators & The secondary indicators & $\begin{array}{c}\text { Entropy } \\
\text { weight }\end{array}$ & $\begin{array}{c}\text { Improved } \\
\text { AHP weight }\end{array}$ & The mean \\
\hline \multirow{2}{*}{$\begin{array}{l}\text { International financial } \\
\text { stability index }\end{array}$} & Ted spread & 0.621012125 & 0.583333333 & 0.602173 \\
\hline & VIX & 0.378987875 & 0.4166666667 & 0.397827 \\
\hline \multirow{5}{*}{$\begin{array}{l}\text { Macroeconomic stability } \\
\text { index }\end{array}$} & The GDP growth rate & 0.331242107 & 0.49072818 & 0.410985 \\
\hline & Inflation rate & 0.127657362 & 0.273527173 & 0.200592 \\
\hline & Fiscal deficit /GDP & 0.148052449 & 0.033341814 & 0.090697 \\
\hline & Current account balance /GDP & 0.146269605 & 0.131738025 & 0.139004 \\
\hline & $\begin{array}{l}\text { Foreign exchange reserves/short- } \\
\text { term foreign debt }\end{array}$ & 0.246778477 & 0.070664808 & 0.158722 \\
\hline \multirow{4}{*}{$\begin{array}{l}\text { Financial market stability } \\
\text { index }\end{array}$} & $\begin{array}{c}\begin{array}{c}\text { Shanghai stock price/earnings } \\
\text { ratio }\end{array} \\
\end{array}$ & 0.131365876 & 0.12267303 & 0.127019 \\
\hline & $\begin{array}{c}\text { The rate at which Banks lend to } \\
\text { each other for seven days }\end{array}$ & 0.299559769 & 0.150835851 & 0.225198 \\
\hline & $\begin{array}{c}\text { The real effective exchange rate } \\
\text { of RMB }\end{array}$ & 0.391538109 & 0.400648439 & 0.396093 \\
\hline & The real estate price index & 0.177536246 & 0.32584268 & 0.251689 \\
\hline \multirow{5}{*}{ Banking stability index } & Bank broad credit growth & 0.341066757 & 0.351984124 & 0.346525 \\
\hline & Inter-bank debt ratio & 0.208806632 & 0.204413082 & 0.20661 \\
\hline & $\begin{array}{c}\text { The bank's non-performing loan } \\
\text { ratio }\end{array}$ & 0.184730726 & 0.188450874 & 0.186591 \\
\hline & Bank capital adequacy ratio & 0.100657914 & 0.137316351 & 0.118987 \\
\hline & Liquidity coverage & 0.164737971 & 0.117835569 & 0.141287 \\
\hline \multirow{3}{*}{$\begin{array}{l}\text { Securities industry stability } \\
\text { index }\end{array}$} & Risk coverage & 0.280822404 & 0.381937083 & 0.33138 \\
\hline & Integrated flow rate & 0.298459982 & 0.213871365 & 0.256166 \\
\hline & Liquidity coverage & 0.420717614 & 0.404191552 & 0.412455 \\
\hline \multirow{2}{*}{ Insurance stability index } & Solvency adequacy ratio & 0.374565034 & 0.285714286 & 0.33014 \\
\hline & Integrated flow rate & 0.625434966 & 0.714285714 & 0.66986 \\
\hline \multirow{3}{*}{$\begin{array}{l}\text { Non-financial sector } \\
\text { stability indicators }\end{array}$} & Local government debt/GDP & 0.269289578 & 0.296296296 & 0.282793 \\
\hline & $\begin{array}{l}\text { The asset-liability ratio of } \\
\text { industrial enterprises }\end{array}$ & 0.438773435 & 0.407407407 & 0.42309 \\
\hline & Household debt /GDP & 0.291936987 & 0.296296296 & 0.294117 \\
\hline
\end{tabular}

\section{The Financial Stability Index Is Calculated by Fuzzy Evaluation Method}

Fuzzy comprehensive evaluation can deal with the subjectivity and the vagueness of people in the process of evaluation. The fuzzy comprehensive evaluation usually follows the following steps:

1. Establish the factor set $U$ of comprehensive evaluation Fuzzy evaluation factor set:

$$
\begin{aligned}
& u=\left\{u_{1}, u_{2}, u_{3}, u_{4}, u_{5}, u_{6}, u_{7}\right\} \\
& u_{1}=\left\{u_{11}, u_{12}, u_{13}, u_{14}\right\} \ldots \ldots .
\end{aligned}
$$

Fig 1. fuzzy evaluation factor set

2. Establish a set of evaluation grade standards $V=\left\{V_{1}, V_{2}, V_{3}, \ldots, V_{m}\right\}$, where is $V_{j}(j=1,2, \ldots, n)$ as the evaluation grade standard, and $n$ is the number of elements, i.e., the number of grades or the number of comment columns. In this article, $n=4$, that is, we have a total of 4 levels of comments, namely stability, potential stability and potential instability, and finally instability. They're assigned $10,35,65,90$. This set defines the selection range of evaluation results of an evaluation factor. Evaluation elements can be qualitative or quantitative.

3. Determine the membership matrix 
Assuming that the evaluation factor is evaluated by a single factor, a relative fuzzy vector $R_{j}=\left(r_{i 1}, r_{i 2}, \ldots, r_{i j}\right), i=1,2, \ldots, n ; j=1,2,3,4$ is obtained. $r_{i j}$ Is the $u_{i}$ 's degree of the factor $V_{j}$. If $\mathrm{n}$ elements are evaluated comprehensively, the result is a matrix of $\mathrm{n}$ rows and 4 columns, which is called membership R. Obviously, each row in this matrix is the evaluation result of each single factor, and the whole matrix contains all the information obtained by evaluating the evaluation factor set $U$ according to the evaluation standard set V. In this paper, the membership degree of qualitative index is determined by expert scoring method, and the membership function is used to calculate the membership degree of quantitative index. According to the requirements of this paper, the membership function of the evaluation system has four evaluation criteria: For the evaluation factors with higher value and greater positive effect on financial stability, the membership degree of these factors is described by the lower half ladder distribution function. The membership functions of 4 levels in each factor corresponding to the comment set are as shown as fig 2.

$$
\begin{aligned}
& r_{1}=\left\{\begin{array}{l}
1,0 \leq u_{i} \leq V_{1} \\
\frac{V_{2}-u_{i}}{V_{2}-V_{1}}, V_{1} \leq u_{i} \leq V_{2} \\
0, u_{i}>V_{2}
\end{array}\right\} \\
& r_{2}=\left\{\begin{array}{l}
0, u_{i} \leq V_{1} \text { 或 } u_{i} \geq V_{3} \\
\frac{u_{i}-V_{2}}{V_{2}-V_{1}}, V_{1} \leq u_{i} \leq V_{2} \\
1, u_{i}=V_{2} \\
\frac{V_{3}-u_{i}}{V_{3}-V_{2}}, V_{2} \leq u_{i} \leq V_{3}
\end{array}\right\} \\
& r_{3}=\left\{\begin{array}{l}
0, u_{i} \leq V_{2} \text { 或 } u_{1} \geq V_{4} \\
\frac{u_{i}-V_{2}}{V_{3}-V_{2}}, V_{2} \leq u_{i} \leq V_{3} \\
1, u_{i}=V_{3} \\
\frac{V_{3}-u_{i}}{V_{3}-V_{2}}, V_{3} \leq u_{i} \leq V_{4}
\end{array}\right\} \\
& r_{4}=\left\{\begin{array}{l}
0, u_{i} \leq V_{3} \\
\frac{u_{i}-V_{3}}{V_{4}-V_{3}}, V_{3} \leq u_{i} \leq V_{4} \\
1, u_{i}>V_{4}
\end{array}\right\}
\end{aligned}
$$

Fig 2. Membership function

$$
\begin{aligned}
& r_{1}=\left\{\begin{array}{l}
1, u_{i}>V_{1} \\
\frac{V_{2}-u_{i}}{V_{1}-V_{2}}, V_{2} \leq u_{i} \leq V_{1} \\
0,0 \leq u_{i} \leq V_{2}
\end{array}\right\} \\
& r_{2}=\left\{\begin{array}{l}
0, u_{i} \leq V_{3} \text { 或 } u_{i} \geq V_{1} \\
\frac{u_{i}-V_{2}}{V_{1}-V_{2}}, V_{2} \leq u_{i} \leq V_{3} \\
1, u_{i}=V_{2} \\
\frac{V_{3}-u_{i}}{V_{2}-V_{3}}, V_{3} \leq u_{i} \leq V_{2}
\end{array}\right\} \\
& r_{3}=\left\{\begin{array}{l}
0, u_{i} \leq V_{4} \text { 或 } u_{1} \geq V_{2} \\
\frac{V_{2}-u_{i}}{V_{2}-V_{3}}, V_{3} \leq u_{i} \leq V_{2} \\
1, u_{i}=V_{3} \\
\frac{u_{i}-V_{4}}{V_{3}-V_{4}}, V_{4} \leq u_{i} \leq V_{3}
\end{array}\right\} \\
& r_{4}=\left\{\begin{array}{l}
0, u_{i}<V_{3} \\
\frac{V_{3}-u_{i}}{V_{3}-V_{4}}, V_{4} \leq u_{i} \leq V_{3} \\
1, u_{i}<V_{4}
\end{array}\right\}
\end{aligned}
$$

Fig 3. 4 levels in each factor corresponding

For the evaluation factors with higher value and greater positive effect on financial stability, the membership degree of these factors is described by the lower half ladder distribution function. The membership functions of 4 levels in each factor corresponding to the comment set are as shown as fig 3 .

Take inflation rate as an example to calculate the relative membership vector of inflation rate. Suppose that the actual value of inflation rate is 1.8 , and the rating standard of inflation rate is as follows:

Table 3. rating standard of inflation rate

\begin{tabular}{|c|c|c|c|c|}
\hline indicators & stable & Potentially stable & Potentially instable & instable \\
\hline Inflation rate & 0 & 4 & 7 & 10 \\
\hline
\end{tabular}

The index is negative, $u=1.8$ and $V_{1} \leq u \leq V_{2}$, according to the formula, is calculated as follows:

$$
\begin{gathered}
r_{1}=\frac{V_{2}-u}{V_{2}-V_{1}}=0.55, \quad V_{1} \leq u \leq V_{2} \\
r_{2}=\frac{u-V_{1}}{V_{2}-V_{1}}, V_{1} \leq u \leq V_{2} \\
r_{3}=0, \quad u<V_{3} \\
r_{4}=0, u<V_{4}
\end{gathered}
$$


Therefore, the relative membership vector of the inflation index is $(0,55,0,45,0,0)$, indicating that China's current inflation rate is zero for stability of $55 \%$. The potential stable membership is 0 . 45. That is, $55 \%$ is stable, $45 \%$ is potentially unstable. According to the steps described above, we can calculate the relative membership vector of other indicators and summarize them to obtain the fuzzy comprehensive evaluation matrix. Then multiply left by the row vector of the weight of the first order index to get the final financial stability index (a probability distribution that measures the stability level).

\section{Summary}

This paper provides a method for regulators to measure financial stability. The improved analytic hierarchy process (AHP) and entropy value method are used to calculate the weights of each secondary indicator to the primary indicator respectively. Different regulators can set different rating standards, for the quality of the fuzzy evaluation method to calculate the financial stability of different regulators may develop different rating standards, the result will be different, so this paper does not give a rating standard, just give an example to illustrate the calculation method, and provide a new way for regulators.

\section{References}

[1]. Xu Gaoxiong, Goo Joanna, Chen Fuping. Construction of China's financial stability index and its leading ability analysis [J]. Statistics and information BBS, 2017, 32(04):27-33.

[2]. Liu Zigong, Wang Qian. The construction and empirical research of China's financial health index -- based on the analysis of the seasonal data from 2007 to 2015 [J]. Modern management science, 2015, (11): 21-23.

[3]. Wang Jimson, Han Keying. Construction of China's jinrong stability indicator system [J]. China's lifting economy, 2015, 29(03):114-124.

[4]. Liu Guiyang. Study on financial stability and its fuzzy evaluation methods [D]. Shanghai university, 2007.

[5]. Yu Hue, Yu Jian. The construction of China's financial situation index and its enlightenment on the transmission effect of monetary policy -- a study based on time-varying parametric state space model [J]. Financial research,2013,(04):85-98. 